\title{
EXPLORING AND TRANSLATING "YONG DOLLAH" LOCAL MALAY STORIES INTO ENGLISH FOR SENIOR HIGH SCHOOL ELT MATERIALS IN BENGKALIS
}

\author{
Boni Saputra ${ }^{1}$, Rionaldi ${ }^{2}$, Aswandi $^{3}$ \\ ${ }^{1}$ English Study Program State Polytechnic of Bengkalis \\ ${ }^{1}$ bonisaputra@polbeng.ac.id \\ ${ }^{2}$ English Study Program State Polytechnic of Bengkalis \\ 2 rio@polbeng.ac.id \\ ${ }^{3}$ English Study Program State Polytechnic of Bengkalis \\ 3 aswandi@polbeng.ac.id
}

\begin{abstract}
Malay story "Yong Dollah" is one of cultural heritage in the form of oral literature in Bengkalis. This story has been very popular and often been told to children, teenagers or even adults in certain occasion like at night or free time. It has been told throughout generations in the life of Malay people in Bengkalis. Yong Dollah is a character created by a man named Abdullah bin Endong, Bengkalis Malay artist. In his entire life, he liked to tell stories that mostly came from his imagination to entertain people. The contents of his stories were often related to his daily life, adventure and often contained certain moral value for audience. The popularity of the stories could be used as learning resource text and media to teach English for senior high school students. However, English version of these stories had never been made before. The exploration and translation of the original stories into English were done to meet the need of learning. Method of translating used in this study was adaptation where intercultural differences between original text from source language (Bahasa Melayu) and target language (English) were adjusted to convey the original meaning from the content of the language. Results of the translation were set of translated stories of Yong Dollah. These Stories can be used by teacher in teaching English for senior high school students. In addition, this study could also be used as alternative entertainment and could help to preserve cultural heritage of Malay people.
\end{abstract}

Keywords: local stories, translation, materials

\section{INTRODUCTION}

Stories of "Yong Dollah" are popular folks literary works that have been a part of life of Bengkalis Malay people. These stories have been inherited throughout generations from time to time. These stories are often told to entertain children as well as adult at certain time or free time at night. Yong Dollah himself is a character created by a man named Abdullah bin Endong, a Bengkalis Malay artist. This man was known as a humorous man, who like to tell funny stories about his imagination and experience. He usually told these stories to people while having drinking a cup of coffee. In sum, Popularity of these stories have been iconic as part of Malay literary heritage.

Existence of funny stories of "Yong Dollah" that contain cultural values can be alternative entertainment for society. However these stories can be even more valuable if it is used in teaching and learning language at high school. These stories can be used in teaching English language in narrative genre based text to students. Yet, English version of these stories have never been available. Due to lack of English references, these stories have never been used in teaching English text at school.

Using local stories in English language teaching could also contributes much in preserving local values for young generations. For that reason, exploring 
and translating these stories into English is urgently needed. The translated Yong Dollah stories can be used in the process of English language learning. The texts can be used as material in reading lesson. Moreover it is expected that using these materials can help students in understanding the content of the stories. Finally, furthermore students of senior high school may get extra benefit from the moral value in the stories.

\section{LITERATURE REVIEW}

2.1 Malay Folk Literature

Mat Piah (2003:5) states that there are two forms of Malay folk literature: the narrative and non-narrative forms. The former is also called folk stories or oral tales, comprising several types such as folklore, exemplary stories, animal fables, humourous stories, myths and legends. Meanwhile, the latter occurs in verse; it includes folk sayings, folk songs, traditional lore, riddles, rhymes, couplets, and satirical poems and others.

Folklore is one of narative forms of folk literature. According to Dundes (1965) in Peow (2015), folklore includes myths, legends, folktales, jokes, proverbs, riddles, chants, charms, blessings, curses, oaths, insults, retorts, taunts, teases, toasts, tongue-twisters, and greeting and leave - taking formulas. It also includes folk costume, folk dance, folk drama (and mime), folk art, folk beliefs (or superstition), folk medicine, etc. Another scholar, Brunvand (1968) in Danandjaja (1995), defines folklore as "those materials in culture that circulate traditionally among members of any group in different versions, whether in oral form, or by means of customary example".

As one type of folklore, folktale can be defined as popular tales or household tales which are rooted in oral tradition and passed down through generations of generally unknown storytellers (Prastiwi; 2015). Majdi (1974), on the other hand, states that folk tales include all the traditional narrative forms such as fairy tales, folk epics, fables, parables anecdotes, and jokes

Aarne and Thompson (1964) in Febriani (2016) states that folktales can be divided into four types:

a. Animal tales: a story in which the main characters are pets or beats and capable to talk more likely human being.

b. Ordinary folktales: an ordinary story in which the main characters are human being, such as: magic tales, religious tales, novella (romantic tales).

c. Jokes and anecdotes: a funny story that make audience laugh.

d. Formula tales: like communicative story: catch tale, and endless tale

Humorous tales are one of narrative forms of Malay folk literature as stated by Mat Piah (2003). They are also known as "jokes" or "amusing anecdotes" (Danandjaja, 1986:118). Traditional humorous tales are grouped into three categories based on the traits of the main characters. They are (1) Idiotic and unlucky: Lebai Malang or the Unfortunate Lebai, and Pak Kaduk or Father Pepperleaf; (2) Wise fool: Pak Pandir or Father Foolish; and (3) Trickters: Pak Belalang or Father Grasshopper, and Si Luncai or Big Belly. (Jihaty Abadi, 1979) According to Peng and Ishak (2009), humorous tales focuses more on the comical aspects and entertaining function narrated in a casual manner. They also have simplified structures. Furthermore, the begins with a casual introduction of the main character, followed by the comical acts portrayed. Usually the main character connects the tales together through several accounts that bind into one whole story involving the said main character. 


\subsection{Folktales in ELT}

Lwin (2015) stated that using literature in teaching English might help to achieve specific purposes of communication of language. It also improve students' cross-cultural awareness. Moreover, it can provide the learners the importance useful basis for developing the four skills. In addition, McKay (1982), suggests that literature give advantages to ESL students. It can develop both theoretical and practical aspects of Linguistic knowledge. Secondly, reading literature is enjoyable for students that it could improve atmosphere of interaction. Yilmaz (2012) conducted research about the students' attitude toward using literature in their teaching. The result showed that most of the students were interested in learning English through literature. The research also suggest a strategy for the teaching of literature will improve both the literary and language competence of students. It also means that using literature in teaching English to students has a lot of advantages.

The use of literature in language teaching has begun in educating children since early $1980^{\mathrm{s}}$. Prastiwi (2015) stated that Indonesian government has taken the literary works into English language teaching for more than 30 years. The government has tried to encourage educator to use traditional literary such as of folk tales in teaching. This is actually bring a lot of benefits for students. (Taylor, 2000) claim that folktales are also useful for developing language learners' awareness of their own culture. It also give chance for the learner to understand the people who speak the language while enjoying the content of the story.

\subsection{Humour and Humorous Stories in ELT}

According to Mat Piah (2003:5) Humorous tales are one of narrative forms of folk tales. Using humorous tales even give more benefits to students English Learning. Hayati et.al (2011) conducted a research about the influence of humor in language teaching. The result of this study suggest significant role of humor and jokes on students' reading comprehension. Benefits of including humor and jokes in the reading texts are available for teachers and students. In the same view, Pham (2014) found that the majority of university EFL teachers and students in her study held positive views of and are in agreement about the roles of humour in EFL teaching. They believed that humour has affective and cognitive benefits for students, their learning, and the teacher-student relationship. Moreover, the majority of the students welcome teachers' use of humour - especially humour in English, and they also believed that humour helps to increase their interest and motivation in learning English.

Magdalena S (1998) states that using humorous stories as supplementary materials in reading comprehension class is beneficial to facilitate a relaxe atmosphere and enjoyment for students. Furthermore, this will stimulate the students to read, improves their reading speed, increases their vocabulary, and broaden their knowledge. She recommends to use culturally humorous stories as supplementary materials in teaching of reading comprehension at senior high school because of their ability to motivate the students to read and provide them cultural knowledge.

\subsection{Translation}

Translation is usually used as term to explain the process of transferring one language to another language, from one kind of communication to another. According to Bell (1991:5) "Translation is the expression in another language (or target language) of what has been expressed in another, source language, preserving semantic and stylistic equivalent" In addition Newmark (1988:5) states that "it is 
rendering the meaning of a text into another language in the way that author intended the text."Based on the definition above, it can be concluded that translation is expressing a message of one language to another language.

\subsubsection{Method of Translation}

A particular method is required in order to make a good translation. The method used in a translation process should be based on the suitable approach for certain text. There are eight translation methods stated by Newmark (1988:45). They are divided into two emphases. The first groups of the methods are called source Language Emphasis; word-for-word translation, literal translation, faithful translation and semantic translation and other groups of the methods are called target language Emphasis.

The detail method of translating text (Newmark: 1988) can be described as the following:

a. Word for Word Translation.

In this method, the words of target language are usually written beneath the words of source language text. In this method the cultural words are translated without considering the context.

b. Literal Translation

The results of this translation method are often based on the grammatical construction of the source language, but the lexical translation is done separately from the context.

c. Faithful Translation

This method produces the contextual meaning of source language text with limitation of grammatical structure.

d. Semantic Translation

In this method, the cultural related words are translated by neutral words.

e. Adaptation

This method is usually used to translate literature such as comedy drama and poem. The elements in a drama such as theme, character, and plot.

f. Free translation

This method emphasizes on the content of the text and ignores the structure of the source language text.

g. Idiomatic translation

This method aims to produce contextual message in a source language text, in order to make the translation of the text can be accepted.

h. Communicative translation

This method emphasizes on the contextual meaning production so that the language aspect and the content can be directly understood.

\subsubsection{Culture and Translation}

Culture has important role in translating process. In translating a cultural text, theories and technical aspects of translation should be determined by considering the genre of the text. It aims to create a good translation which is closer to the meaning in target language. The experience and the background knowledge of a translator are needed in the translation process.

Furthermore, according to Ainon and Hassan (2005), there are two important aspects should be translated. The aspects of cultural translation can be described as the following: 


\section{Language translation}

The translator should be able to communicate with the language of source language sender (speaker/writer).

2. Cultural translation

The translator should be able to create a translation which telling the reader about what they are reading. It is including a person, things, something or culture.

\subsubsection{Translating Cultural Text}

Each language has its own pattern to show the relationship between people and events. Therefore, the translator should have broad insight in order to create a good and understandable translation. The selection of appropriate method of translation is also necessary. Ainon and Hassan (2005) states that in translating terms of cultural background should consider some important aspects, they are: cultural elements are maintained, cultural elements are omitted and Cultural elements are re adjusted. Based on the definition above, it can be concluded that in translating some text, the translator should pay attention to the culture of the source and target language of the text.

Adaptation method is an effective method which can be applied in translating a narrative text. Taryadi (2003) states that adaptation is the most independent method, and has often been used to translate literature works such as comedy drama and poem. In this method, the culture of source language text is rendered to the culture of target language text by adapted them.

\section{METHODS}

Method used in this research was qualitative. The research was conducted to explore and translate stories of Yong Dollah. The purpose of the research was to provide translated material of the Yong Dollah's funny stories for ELT materials. The data collection of the research was done by doing literature study, observing, interviewing, recording, transcripting, and translating. Firstly, the researchers did literature study from books of Malay stories and other references. Then researchers gathered data of the original stories of Yong Dollah by observing and interviewing people that have knowledge about these stories. Next, the stories gathered were recorded and transcripted into Bahasa Indonesia. Finally, the transcripted stories were translated into English. The script of translated study is expected to provide alternative teaching and learning materials for English lesson in Senior high schools.

\section{FINDINGS AND DISCUSSION}

The researchers started the research by conducted literature study. It is done to find out whether there is enough information about original Yong Dollah Stories to be used as parts of materials to be translated. As a consequence, the researcher did visits to several campus and public library in Pekanbaru and local public library in Bengkalis Regency. Based on these visits, it was found that there are only limited references about original story of Yong Dollah. Only one Author found has ever written these stories. The author is one of Bengkalis Malay who works as a lecturer at Bahasa Indonesia Departement in a private universitiy in Pekanbaru. Due to, the tight schedule of the author interview in could not be done to find more information. This limited information was not satisfying enough to for the research.

Then, the research was continued to observing and finding information by interviewing people who have knowledge of original story from the original sources; 
Yong Dollah. There were some people involving in these interviews. These people had experience in listening the original stories and had been mingled with Yong Dollah. These interviews resulted several original stories of Yong Dollah. Most of the stories are about Yong's strange experience in his daily life. These stories were about "Animal Race, Following a Hunting Competition in Afrika, Yong and the mouse deer, young as a ship captain. The stories resulted were recorded in Malay language. Then, the stories were transcripted into Bahasa Indonesia before translated into English. The transcripted stories in Bahasa was used to translate the stories into English.

Below is an example of transcripted Stories in Bahasa and the English translation:

\begin{tabular}{|c|c|}
\hline Transcripted Story (Bahasa Indonesia) & Translation Result (English) \\
\hline $\begin{array}{l}\text { Lomba Lari Hewan } \\
\text { Alkisah, dahulu yong dollah memelihara seekor } \\
\text { anjing, berbeda dengan orang-orang di } \\
\text { kampungnya yang memelihara sapi, kuda, } \\
\text { harimau, dan lainnya. Pada suatu hari, diadakan } \\
\text { lomba lari untuk hewan-hewan peliharaan. } \\
\text { Banyak orang yang berminat mengikuti } \\
\text { perlombaan tersebut. mereka membawa hewan } \\
\text { peliharaan seperti sapi, kuda, dan harimau. } \\
\text { Yong juga tertarik untuk ikut lomba tersebut. } \\
\text { Namun, hanya yong yang membawa anjing. } \\
\text { Ketika semua hewan sudah berbaris, } \\
\text { perlombaan pun dimulai dalam hitungan } 1 \\
\text { sampai 3. Semua hewan sudah berlari namun } \\
\text { hanya anjing yang tetap ditempatnya dan sama } \\
\text { sekali tidak bergerak. Yong pun berfikir keras } \\
\text { bagaimana agar si anjing mau berlari. Akhirnya } \\
\text { ia pun menemukan sebuah ide. Ia memoleskan } \\
\text { balsem pada punggung hewan peliharaannya } \\
\text { tersebut. alhasil, si anjing pun berlari sangat } \\
\text { cepat karena kepanasan. Anjing pun } \\
\text { memenangkan perlombaan tersebut karena } \\
\text { panas balsem yang di oles kan. Ketika } \\
\text { hewannya menjadi pemenang, banyak orang } \\
\text { yang merasa marah dan heran atas kemenangan } \\
\text { seekor anjing. Karena biasanya kuda yang } \\
\text { selalu menjadi pemenang dalam perlombaan } \\
\text { seperti itu. Kemudian wartawan pun bertanya } \\
\text { kepada yong bagaimana bisa anjingnya } \\
\text { memenangkan perlombaan tersebut. lalu dengan } \\
\text { berbisik yong menjawab "saya oleskan balsem } \\
\text { pada punggung". }\end{array}$ & $\begin{array}{l}\text { Animals Race } \\
\text { Several years ago, Yong kept a pet at his home. } \\
\text { Unlike his neighbor in his village who keep } \\
\text { cow, horse, tiger and etc as pet, Yong kept a } \\
\text { dog. One day, there was a race of animal held } \\
\text { in the village. Many people were interested in } \\
\text { joining the race. They bring pets like cows, } \\
\text { horses, and tigers. Yong was also interseted in } \\
\text { joining the animals running race with his pet } \\
\text { However, only yong who brought the dog. On } \\
\text { the race day, all animals are ready to start the } \\
\text { running including his dog. When all the animals } \\
\text { are lined up, the race begins in a count of } 1 \text { to } 3 . \\
\text { All animals are running but only his dog remain } \\
\text { in place and not moving at all. Yong was } \\
\text { thinking so hard to find out how to make the } \\
\text { dog run. Finally, he got an idea. He put } \\
\text { something on the dog's back. Then, the dog } \\
\text { was running very fast and made the crowd } \\
\text { shocked. They couldn't believe what they had } \\
\text { seen. Surprisingly, the dog won the race. When } \\
\text { the animal becomes the winner, many people } \\
\text { feltt angry and astonished at the victory of the } \\
\text { dog. It was because the winner of the previous } \\
\text { races were usually horse. Then, the reporter on } \\
\text { duty to report the race asked yong what he did } \\
\text { to make his dog won the race. What could make } \\
\text { your dog run very fast and won the race yong? } \\
\text { asked the reporter. Then, yong whisperedly } \\
\text { replied "I put balm on its back". }\end{array}$ \\
\hline
\end{tabular}

The example translation of the stories revealed that cultural context of the story like keeping dog as a pet in western culture is normal for people. The funny side of the story did have strength to be used in EFL context, especially for Malay students. On the other hand, western people will find that strange to keep animals like cow to be a pet. However, in the translation process, the translator tried to convey all message that the original text contain. Overall, the result of translated stories give benefits for students. It is easier to be understood by EFL students due to cultural content of the story. 
Another example of translated story were shown in the following:

Following A Hunting Competition In Afrika
Yong dolah was invited to represent Bengkalis in joining a world hunting competition in Afrika.
However, the competition was quite different from other hunting competition. The finalists should
take the skin of the animal without hurting the skin. The first finalist was from japan. He tried to
hunt the elephant slowly. He shot the elephant with his gun. But, his gun hurt the elephant's skin
dramatically. Unluckily the judges declared that the finalist from japan failed. The next finalist was
from USA. Confidently, he shot the zebra that was eating the grass. Once more, he also broke the
zebra's skin and also declared failed. Last participant, yong dollah, was called to hunt. He chose to
shot the tiger and taking the skin. Yet, he thought really hard to hunt animal without hurting it's skin.
Finally he had an idea, he tried to walked slowly on the bushes. He shot the tiger tail while the tiger
was eating. The tiger was really shocked and left his skin behind him. Finally Yong got the animal
skin without hurting it. Yong dolah became the winner on the world hunting competition.

The results of the Yong Dollah's humorous stories, shows that the made up stories delivered by Yong Dollah are fun and imaginative. These stories are good to use students' imagination in learning and can improve their motivation to learn English language.

\subsection{Discussions}

A research result conducted by Yilmaz (2012) suggest that using literature in teaching has positive impact to students' attitude toward learning. This is in line with McKay (1982), literature could benefit students in learning both theoretical and practical aspects of language. This is to say that using literature could improve the students' learning of English.

Magdalena S (1998) states that using humorous stories as supplementary materials in reading comprehension class is beneficial to facilitate a relaxe atmosphere and enjoyment for students. Furthermore, this will stimulate the students to read, improves their reading speed, increases their vocabulary, and broaden their knowledge. She recommends to use culturally humorous stories as supplementary materials in teaching of reading comprehension at senior high school because of their ability to motivate the students to read and provide them cultural knowledge.

Since Yong Dolah humorous stories have been popular among Bengkalis people, presenting them in English language teaching as suplementary materials is seen as a good learning innovation in language learning. A research conducted by Nuraini (2015) found that humour used by teacher significantly influence students' interest toward English. Maulidah (2015) also found that learning English through funny story technique could increase students' learning outcome. Similarly, Pham (2014) also found that the majority of university EFL teachers and students in her study held positive views of and are in agreement about the roles of humour in EFL teaching. They believed that humour has affective and cognitive benefits for students, their learning, and the teacher-student relationship. Moreover, the majority of the students welcome teachers' use of humour - especially humour in English, and they also believed that humour helps to increase their interest and motivation in learning English.

Based on the discussion above, it can be concluded that using literature; Malay funny story of Yong Dollah could give positive effects on students' learning. It could give enjoyable atmosphere of learning since the students enjoy the cultural content of the story. Moreover it could also improve the students' knowledge of the language. In sum these stories are suitable to be used as supplementary materials for learning English. 


\section{CONCLUSION}

Funny stories of "Yong Dollah" that contain cultural values can be used in teaching and learning language at high school. Using local stories in ELT could also contributes much in preserving local values for young generations. For that reason, exploring and translating these stories into English was done to provide the texts material for students English learning. Moreover these materials can help students in learning Reading. Furthermore students of senior high school may get extra benefit from the moral value in the stories

The research were done in several steps. Literature study was first done to provide enough information about original stories of Yong Dollah. The writer did the literature study by visiting libraries. The findings revealed that there are only limited references about original story of Yong Dollah. Then, field observation and interview were done to gather more information about the original stories. These activities could result several original stories of Yong Dollah. Most of the stories are about Yong's strange experience and events in his life. Then, the stories were transcripted into Bahasa Indonesia before translated into English. The transcripted stories in Bahasa was used to translate the stories into English.

The translation result of the stories revealed that cultural context of the story did have strength to be used in EFL context, especially for Malay students. Since Yong Dolah humorous stories have been popular among Bengkalis people, presenting them in English language teaching as suplementary materials is seen as a good learning innovation in language learning Overall, the result of translated stories give benefits for students. It is easier to be understood by EFL students due to cultural content of the story.

\section{REFERENCES}

Ainon Mohd dan Adullah Hassan (2005). Teori Dan Teknik Terjemahan. Edisi Ketiga Kuala Lumpur : PTS Publications \& Distributors Sdn. Bhd.

Bell, R.T. (1991). Translation and Translating: Theory and Practice. Longman: London

Danandjaja, James. (1986). Folk Literature Indonesia. Jakarta: Grafitipers.

Danandjaja, James. 1995. A Comparative Study of Japanese and Indonesian Folklores. 東南アジア研究 (1995), 33(3): 484-496

Febriani, Yolanda. 2016. Story Structure And Function Analysis Of Four Muratara Folktales Using Propp's Morphology. State Polytechnic of Sriwijaya

Lwin, S.M. Using Folktales for Language Teaching. Melta; Malaysian Journal of ELT Research. XLIV(2). 2015.

Magdalena, J. S, . (1998) Using humorous stories as supplementary materials in the teaching of reading comprehension at SMU. Undergraduate thesis, Faculty of Teacher Training and Education.

Majdi W (1974). A Dictionary of Literary Terms. Library of Lebanon. Beirut.

Mat Piah, 2003. Sastera Rakyat Malaysia, Indonesia, Negara Brunei Darussalam:Suatu perbandingan. Kuala Lumpur: Dewan Bahasa \& Pustaka

Maulidah, Siti (2015) Upaya Meningkatkan Kosa kata Bahasa Inggris Melalui Funny Story pada Siswa Kelas VIII Madrasah Tsanawiyah Zainul Aziz Tamban Kabupaten Barito Kuala. Skripsi, Tarbiyah dan Keguruan. 
McKay, S. L. (2001). Literature as content for ESL/EFL. In M. Celce-Murica (Ed.), Teaching English as a Second/Foreign Language (pp.319-332). New York, NY: Heinle and Heinle.

Newmark, P. (1988). A texbook of Translation. New york: Prentice Hall.

Nuraini. 2015. Pemberian Humor oleh Guru Terhadap Minat Belajar Bahasa Inggris

Pada Siswa. Universitas Negeri Sultan Syarif Kasim Riau

Pham, Hoang Nguyen Huy. 2014. The use of humour in EFL teaching: A case study of Vietnamese university teachers' and students' perceptions and practices. University of Canberra, Australia

Peng, Chew Fong., Zahari Ishak. 2009. Malay Literature in Early Childhood Education among Malaysians. International Journal for Educational Studies, 2(1) 2009

Peow, See Hoon. 2015. Malaysian Chinese Stories of Hard Work:Folklore and Chinese Work Values IJAPS, Vol. 11, No. 2, 1-16, 2015

Prastiwi, 2015. Folktales as a medium of teaching English: two primary schools in Solo, Indonesia. Deakin University

Taryadi, A. (2003). Kritik Terjemahan di Indonesia. Kompas 5 November 2003

Taylor, E. K. (2000). Using folktales. Cambridge: Cambridge University Press.

Yilmaz, cevdet. Introducing Literature to an EFL Classroom: Teacher's Instructional Methods and Students' Attitudes toward the Study of Literature. English Language Teaching Journal. Canadian Center of Science 5 (1) 2012. 